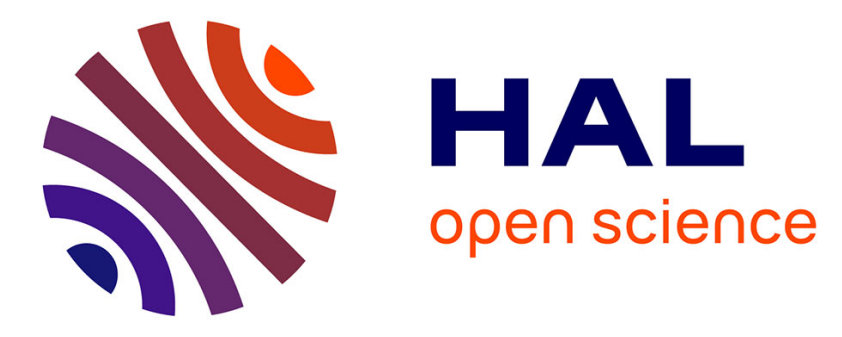

\title{
Surface chemistry-mediated metal nanoclusters for in vivo shortwave infrared imaging
}

Xavier Le Guével, Benjamin Musnier, Karl Wegner, Maxime Henry, Agnes

Desroches-Castan, Ute Resch-Genger, Sabine Bailly, Yves Usson, Véronique Josserand, Jean-Luc Coll

\section{To cite this version:}

Xavier Le Guével, Benjamin Musnier, Karl Wegner, Maxime Henry, Agnes Desroches-Castan, et al.. Surface chemistry-mediated metal nanoclusters for in vivo shortwave infrared imaging. Colloidal Nanoparticles for Biomedical Applications XVI, Mar 2021, Online Only, France. pp.14, 10.1117/12.2577451 . hal-03373560

\section{HAL Id: hal-03373560 https://hal.science/hal-03373560}

Submitted on 11 Oct 2021

HAL is a multi-disciplinary open access archive for the deposit and dissemination of scientific research documents, whether they are published or not. The documents may come from teaching and research institutions in France or abroad, or from public or private research centers.
L'archive ouverte pluridisciplinaire HAL, est destinée au dépôt et à la diffusion de documents scientifiques de niveau recherche, publiés ou non, émanant des établissements d'enseignement et de recherche français ou étrangers, des laboratoires publics ou privés. 


\section{Surface chemistry-mediated metal nanoclusters for in vivo shortwave infrared imaging}

In vivo optical imaging is nowadays widely used for cancer diagnosis and imageguided therapy with various devices that have already entered into the clinic. However, current fluorescence imaging is worth improving in spatial and temporal resolution in deep tissues. A novel approach relies on collecting optical signal from the second near-infrared window between 900 to $1700 \mathrm{~nm}$ called Shortwave InfraRed (SWIR). The use of this wavelength range should considerably reduce light scattering and absorption by blood and tissues in vivo improving sensitivity and spatial resolution in depth [1-3].

There is a high need to develop bright and safe contrast agents in this spectral window especially with emission at longer wavelength $(>1250 \mathrm{~nm})$. In this context we develop gold nanoclusters (Au NCs) with different surface chemistry to enhance and red-shift their photoluminescence to the SWIR windows [3-4].

We evaluated then the impact of light scattering effects on spatial resolution in different shortwave infrared (SWIR) sub-regions by analyzing two SWIR emissive phantoms made i) polydimethylsiloxane (PDMS)-Au NCs composite covered with mice skin, and ii) capillary tubes filled with Au NCs at different depth in intralipids. We demonstrated the significant improvement of spatial resolution and reduced scattering collecting photons in the second SWIR windows between 1500 and $1700 \mathrm{~nm}$ and confirmed these results in mice with the observation of the blood network few mm deeper in mice [5].

New imaging processing methods are also necessary to enable sharp and detail reconstruction deeper in tissues. To address a clinical need for non-invasive highresolution imaging of vascular and lymphatic networks at cellular level, we propose the use of a new bright SWIR emitting contrast agent based on ultra-small gold nanoclusters in pathological animal models presenting vascular disorders. We report also new imaging methods based on a series of Monte Carlo restoration (MCR) and on segmental analyses to provide a highly detailed mapping on the vasculature of mice. Imaging processing based on MCR enables more than one order improvement of spatial resolution with reduced scattering to distinguish non-invasively blood vessels deeper than $4 \mathrm{~mm}$. Segmentation analyses showed an increase of vessels complexity in transgenic mice KO BMP9 which confirmed previous ex vivo studies performed at the cellular level [6].

In conclusion, we presented new a method of high resolution, non-invasive, in vivo vascular imaging obtained using water-soluble and bright SWIR-emitting gold nanoclusters presenting an anisotropic surface charge combined with SWIR detection and Monte Carlo processing of the images. We applied this approach to quantify vessel complexity in mice presenting vascular disorders.

\section{Acknowledgement}

Xavier Le Guevel would like to thank l'agence pour la recherche contre le cancer ARC (RAC17012CCA) and Plan cancer (C18038CS) fundings.

\section{References}

[1] G. Hong, A. Antaris, H. Dai, Nature biom. Eng. 2017, 1, 0010 (0011-0022)

[2] O. Bruns, ..., M. Bawendi, Nature biom. Eng. 2017, 1, 0056(0051-0011)

[3] Y. Chen, D. Montana, H. Wei, J. Cordero, M. Schneider, X. Le Guevel, O. Chen, O. Bruns, M. Bawendi, Nanoletters 2017, 17, 6330-6334.

[4] B. Musnier, K. D. Wegner, C. Comby-Zerbino, V. Trouillet, M. Jourdan, I. Hausler, R. Antoine, J. L. Coll, U. Resch-Genger, X. Le Guevel, Nanoscale 2019, 11, 12092-12096.

[5] B. Musnier, M. Henry, J. Vollaire, J.-L. Coll, Y. Usson, V. Josserand, X. Le Guével, Journal of Biophotonics 2020, n/a, e202000345.

[6] Z. Yu, B. Musnier, K. D. Wegner, M. Henry, B. Chovelon, A. Desroches-Castan, A. Fertin, U. Resch-Genger, S. Bailly, J.-L. Coll, Y. Usson, v. josserand, X. Le Guével, ACS Nano 2020, 14, 4973-4981. 